\title{
PENOLAKAN KONSEP KETUBUHAN PATRIARKIS DI DALAM PROSES MENJADI PEREMPUAN MELALUI PEMIKIRAN MERLEAU-PONTY DAN SIMONE DE BEAUVOIR
}

\section{Retno Daru Dewi G. S. Putri}

Program Magister Filsafat

Fakultas Ilmu Pengetahuan Budaya, Universitas Indonesia

Email : darugsp@yahoo.com

\section{Abstrak}

Dualisme mind dan body yang disampaikan oleh Descartes menunjukkan adanya relasi antara jiwa dan tubuh di dalam menyampaikan pemikiran manusia. Konsep ini kemudian bergeser akibat konstruksi sosial yang membedakan manusia berdasarkan jenis kelamin dan gendernya. Diskriminasi yang terjadi menunjukan adanya kekurangan filsafat di dalam menanggapi permasalahan manusia secara universal. Di dalam menanggapi permasalahan yang terjadi, penelitian ini menggunakan konsep persepsi yang menubuh Merleau-Ponty untuk menekankan pentingnya tubuh perempuan yang bebas di dalam memahami fenomena yang terjadi di dunia. Selain itu, kesadaran akan ambiguitas yang disampaikan oleh Beauvoir dapat dipadukan dengan pemikiran Merleau-Ponty agar perempuan memahami banyaknya pilihan yang dapat ditentukan secara mandiri. Dengan penerapan pemikiran Merleau-Ponty dan Beauvoir, proses menjadi perempuan atau becoming a woman dapat dilalui secara mandiri dan menjadi solusi yang dihadirkan oleh filsafat untuk isu feminisme.

Kata-kata Kunci: persepsi yang menubuh, ambiguitas, feminism, persepsi yang menubuh Merleau Ponty, konsep ambiguitas Beauvoir.

\section{Abstract}

Descartes' dualism of mind and body implies relationship of mind and body in the articulation of human thinking. While seemingly reflects both men and women, this concept of dualism has in practice changed due to the existing social construction that differentiate human based on their sex. The ongoing social discrimination against women implies philosophy's 
deficiency in addressing human universal issues. In addressing this issue, this research emplyos Merleau-Ponty's notion of embodied perception and Beauvoir's conception on ambiguity to argue on the importance of women's body freedom in understanding the world's phenomenons around them. The application of these concepts is proposed to provide an independent mode of becoming a woman and to offer a philosophical solution for women's issues. Keywords: embodied perception, ambiguity, feminism, Merleau Ponty, Beauvoir

\section{PENDAHULUAN}

Ketubuhan adalah suatu konsep yang tidak dapat dihindari oleh manusia. Pemikiran yang menjadi hasil interpretasi manusia terhadap dunia tidak akan mampu tersampaikan apabila tidak ada tubuh yang hadir sebagai media untuk menyampaikan hasil kontemplasi tersebut. Hubungan antara pemikiran dan tubuh manusia disinggung oleh René Descartes yang mengutamakan mind di atas body dalam mendefinisikan manusia. Konsep dualism mind dan body milik Descartes mendapat justifikasi dari hasil pemikiran para filsuf yang hadir sebelum maupun sesudah penyampaian mind dan body miliknya. Sebagai contoh, Plato memaparkan bahwa tubuh manusia adalah fasilitas yang penting untuk mencapai suatu tujuan di dalam hidup. Hal ini menunjukkan bahwa walaupun berbeda zaman, para filsuf melihat adanya satu konsep dari manusia yang serupa bahwa jiwa dan raga adalah satu kesatuan.

Walaupun pemikiran para filsuf mengenai tubuh tidak jauh berbeda, seiring berkembangnya waktu berbagai pemikir lain hadir dengan konsep-konsep lain yang melengkapi pemikiran tentang ketubuhan manusia. Spinoza misalnya, menambahkan aspek ketuhanan di dalam pemahamannya mengenai konsep tubuh. Spinoza menyampaikan bahwa tubuh manusia akan bermanfaat apabila mampu merepresentasikan Tuhan pada setiap kegiatannya (Woolhouse, 1993: 31). Para filsuf modern turut memoles pengertian mengenai konsep ketubuhan manusia dengan pemikiran-pemikiran mereka. Salah satu filsuf modern yang ikut menyempurnakan makna ketubuhan adalah Gottfried Wilhem Leibniz. Leibniz menganggap 
tubuh sebagai automata atau mesin yang paling sempurna bagi manusia (Bennett, 2017: 1). Pemikiran-pemikiran dari para filsuf menunjukkan adanya sifat manusia yang sama menyangkut konsep ketubuhan yaitu bersatunya jiwa dan raga.

Persamaan konsep akan ketubuhan yang serupa pada akhirnya goyah karena adanya kondisi sosial yang mengharuskan manusia saling bersinggungan di dalam kehidupannya. Peran manusia yang terdiri dari perempuan dan laki-laki mulai terlihat berbeda. Salah satu contoh mulai diterapkannya perbedaan peran manusia di dalam kehidupan sosial adalah pada pemaparan Thomas Hobbes yang menyatakan bahwa perempuan lebih unggul di dalam merawat anakanaknya sedangkan laki-laki lebih berkuasa di dalam kehidupan berumah tangga (Agonito, 1977: 95). Meneruskan konsep pemikiran yang serupa, John Locke menambahkan bahwa konsep penerapan kekuasaan dimulai dari Ayah. Di sisi lain, Ibu ditempatkan sebagai pihak yang lebih layak untuk mengurus anak (Agonito, 1977: 100). Dari pemaparan tersebut, terlihat bahwa konsep ketubuhan perempuan mulai dianggap berbeda dari laki-laki.

Konsep ketubuhan yang mengunggulkan laki-laki dan menunjukkan keunggulan yang opresif dan diskriminatif (Asante \& Mazama, 2005: xxv) menjadi hal yang mewarnai filsafat. Plato dan Aristoteles, sebagai contoh, memiliki konsep yang sama bahwa perempuan hanya menghadirkan tubuhnya sebagai pelengkap lakilaki. Konsep yang diskriminatif ini terus berkembang mewarnai kehidupan sosial manusia. Immanuel Kant adalah salah satu pemikir yang menghadirkan perbedaan diantara perempuan dan laki-laki berdasarkan kelas sosialnya (Kant, 1977: 129-144). Perilaku yang berbeda untuk perempuan juga dipaparkan oleh Schopenhauer yang memiliki pemikiran bahwa tubuh perempuan berfungsi untuk anakanak yang ia lahirkan. Hal ini menunjukkan ketatnya kekangan konsep ketubuhan patriarkis terhadap pergerakan perempuan di dalam kehidupan bermasyarakat. Kekangan yang disebabkan oleh perbedaan di antara perempuan dan laki-laki tersebut dilengkapi oleh pemikiran Sartre mengenai perempuan sebagai the other yang memiliki fungsi melengkapi laki-laki. Diskriminasi yang mengekang 
menjadi batasan perempuan untuk bergerak dengan tubuh mereka sebagai media baik fisik maupun sosial. Hal ini bertentangan dengan sifat manusia yang dianggap memiliki substansi-substansi utuh tanpa membedakan jenis kelamin yang ada (Leahy, 2001: 18).

Konsep ketubuhan patriarkis mendapat sanggahan dari para pemikir feminis. Kritik dan perlawanan yang dilakukan oleh para feminis dipicu oleh pemikiran penis envy yang disampaikan oleh Freud. Salah satu pemikir feminis, Chodorow, menekankan bahwa penis envy bukan sumber dari masalah yang terjadi pada perempuan dan laki-laki. Ia mengemukakan besarnya pengaruh cara asuh orang tua yang menentukan tindakan manusia dewasa. Oleh karena itu, penis envy bukanlah fenomena yang terjadi pada perempuan. Kristeva turut menyanggah pemikiran kaum patriarki dengan pemikiranpemikirannya. Ia menghadirkan konsep Abjeksi sebagai karakter perempuan yang harus diterima dan dijauhkan dari sifat jijik terhadap tubuh perempuan seperti yang selama ini terjadi.

Pada tulisan ini, pemikir feminis berikutnya lah yang akan dipinjam, dianalisa, serta diterapkan teorinya di dalam menolak konsep ketubuhan patriarki, yaitu Simone de Beauvoir. Pemikir Beauvoir hadir dengan konsep proses menjadi perempuan atau becoming a woman. Beauvoir memaparkan tentang tantangan bagi perempuan dan yang tidak pernah dialami oleh laki-laki. Selain adanya konsep other yang diasosiasikan dengan perempuan, pada karyanya The Second Sex, Beauvoir memaparkan kondisi sosial yang membentuk konsep perempuan itu sendiri. Perilaku berbeda yang dikenakan kepada perempuan merupakan hasil diskriminasi kaum patriarki yang menjadikan rahim sebagai justifikasi untuk merendahkan posisi perempuan di dalam kehidupan sosial. Hal ini lah yang menyebabkan kekangan yang dialami oleh perempuan tetap terjadi walaupun perkembangan filsafat dan ilmu pengetahuan sudah jauh melesat dari sebelumnya. Dengan majunya filsafat dan ilmu pengetahuan, seharusnya seperti apa yang pernah disampaikan oleh Descartes, filsafat mampu untuk menjawab permasalahan universal manusia (Arivia, 2003: 39). Akan tetapi, dengan permasalahan 
feminisme yang masih terjadi, kemampuan filsafat di dalam memberikan solusi di dalam hidup manusia patut dipertanyakan.

Di dalam menjawab permasalahan perempuan secara filsafat, tulisan ini mengajukan solusi untuk menolak konsep ketubuhan patriarki dengan menerapkan pemikiran milik Merleau-Ponty. Persepsi yang menubuh milik pemikir asal Prancis tersebut dapat mendobrak kaum patriarki yang selama ini mengekang pergerakan tubuh perempuan. Konsep milik Merleau-Ponty dipadukan dengan kesadaran akan ambiguitas yang dipaparkan oleh Beauvoir pada karyanya The Ethics of Ambiguity. Dengan konsep yang disampaikan oleh Merleau-Ponty dan Beauvoir, proses menjadi perempuan atau becoming a woman dapat dilalui secara mandiri tanpa dominasi dari kaum patriarki.

\section{PEMBAHASAN}

\section{Perkembangan Konsep Ketubuhan Perempuan di dalam Filsafat}

Permasalahan feminis di dalam filsafat tidak lepas dari struktur pemikiran yang didominasi oleh kaum patriarki. Para filsuf dari era yang berbeda-beda memaparkan konsep yang mendiskriminasi tubuh perempuan. Pada Era Filsuf Yunani, misalnya, Plato dan Aristoteles menyampaikan konsep yang menghadirkan fungsi utama perempuan sebagai pelengkap laki-laki yang mana tubuh perempuan dibatasi hanya sebagai alat bantu reproduksi. Konsep yang diskriminatif seperti ini tidak hanya berhenti pada masa Plato dan Aristoteles saja. Pada Abad Pertengahan aspek-aspek baru diterapkan oleh para pemikir untuk melengkapi konsep ketubuhan perempuan. Agustinus dan Aquinas, misalnya, menggunakan agama sebagai justifikasi agama untuk menguasai dan membelenggu pergerakan perempuan. Apabila perempuan tidak mematuhi laki-laki, maka mereka dianggap melanggar ketetapan gereja dan layak diberikan hukuman secara fisik.

Pengekangan yang terjadi pada Abad Pertengahan tidak berhenti begitu saja. Seiring berjalannya waktu serta berkembangnya filsafat dan ilmu pengetahuan, konsep ketubuhan perempuan yang 
diharapkan berkurang masih terjadi. Akan tetapi, kekangan akan tubuh perempuan secara fisik dan sosial bergeser ke ranah kehidupan bermasyarakat. Pemikir seperti Descartes dan Nietszche menempatkan perempuan pada posisi yang lebih rendah daripada laki-laki di dalam lingkup sosial. Era ini kemudian mendapatkan kritikan dari pemikir-pemikir feminis yang menuntut adanya kesetaraan hak untuk mendapatkan pendidikan yang sama dengan laki-laki.

Tuntutan yang disampaikan oleh para feminis bertambah dengan adanya konsep yang disampaikan oleh Freud. Di abad ke-20, Freud menyatakan adanya penis envy yang dimiliki oleh perempuan akibat tidak adanya phallus (Freud, 1920:142). Konsep ini menjadi pemicu kemarahan feminis hingga saat ini. Pemikiran seksualitas Freud dianggap tidak sahih karena tidak pernah disertai dengan penelitian anatomi tubuh wanita. Selain Freud, filsuf-filsuf di Era Kontemporer seperti Deluze dan Baudrillard, keduanya menempatkan perempuan pada posisi yang lebih rendah akibat dari aspek seksual perempuan yang dipandang tidak selengkap laki-laki yang memiliki phallus.

Seiring perkembangan zaman sayangnya pemikiran para filsuf dipandang belum mampu melepaskan dari diskriminasi terhadap konsep ketubuhan perempuan. Apabila hal ini tetap terjadi, maka apa yang telah disampaikan oleh Descartes bahwa filsafat dapat menjadi jawaban permasalahan universal manusia (Arivia, 2003:39) tidak dapat diakui. Oleh karena itu, para pemikir feminis berusaha memberikan sanggahan untuk menolak konsep ketubuhan patriarkis.

Perjuangan para feminis dimulai dengan pemikiran para filsuf Feminis Liberal seperti Wollstonecraft, Mill, Taylor, dan Friedan. Mereka memulai perjuangannya dengan menuntut kesetaraan perempuan di bidang pendidikan dan ekonomi. Wollstonecraft melihat adanya potensi perempuan yang dapat dikembangkan untuk menjadi setara dengan laki-laki apabila mereka diberikan hak untuk menempuh pendidikan yang sama. Di bidang ekonomi, Mill dan Taylor mengembangkan tuntutan akan kesetaraan agar perempuan mampu meraih kondisi ekonomi yang sama dengan laki-laki. Selain bidang pendidikan dan ekonomi, pemikir feminis asal Amerika 
Serikat, Friedan, menghadirkan permasalahan perempuan yang berawal dari lingkup domestik (Friedan, 2013:172-176). Masalah yang disebut dengan the problem that has no name tersebut menunjukkan adanya kekosongan yang dialami oleh perempuan-perempuan Amerika di dalam kehidupan berumah tangga. Mereka selama ini menganggap pencapaian tertinggi perempuan adalah menjadi ibu rumah tangga. Akan tetapi, pencapaian tersebut hanya membuat mereka menjadi depresi.

Perjuangan para Feminis Liberal diteruskan oleh Feminis Radikal yang secara langsung memusatkan perhatian pada ketubuhan perempuan. Dua pemikir di era ini adalah Millet dan Koedt. Konsep yang ditentang oleh Millet mengarah pada kuasa lakilaki di dalam konsep ketubuhan dan seksual perempuan. Sedangkan Koedt mengkritik pemikiran Freud mengenai konsep orgasme vaginal. Hal ini disanggah karena Freud tidak secara langsung menganalisa anatomi tubuh perempuan.

Pemikir Feminis Liberal dan Radikal diteruskan oleh Feminis Marxist dan Sosialis, seperti Hartmann. Pemikiran marxisme yang memiliki potensi untuk digabungkan dengan feminism ditolak oleh Hartmann. Hal ini disebabkan oleh adanya hirarki yang dikemukakan oleh Marx di dalam teorinya tidak dapat mendukung kesetaraan yang diutamakan oleh feminisme. Hirarki yang mengekang ketubuhan perempuan secara sosial inilah yang menjadi perlawanan yang dilakukan oleh Feminisme Marxist dan Sosialis.

Feminis-feminis berikutnya tergabung di dalam Feminisme aliran Psikoanalitik. Pemikir pada era ini melihat adanya celah pada teori yang disampaikan oleh Freud. Pendapat penis envy yang disampaikan oleh Freud menjadi pemicu berbagai penolakan dari para feminis. Sebagai contoh, Kristeva menghasilkan konsep abjeksi untuk melawan rasa jijik terhadap ketubuhan perempuan. Ia menyatakan;

The difference between the sexes ultimately cuts back through early childhood, dividing up functions and sexual roles: "maleness 
combines (the factors of) subject, activity, and possession of the penis; femaleness takes over (those of) object and passivity" and the castrated genital organ (Irigaray, 1985: 36).

Perbedaan di antara jenis kelamin yang ada kembali kepada awal masa kanak-kanak, yang membagi fungsi seksual dan peranannya: "kelaki-lakian mengkombinasikan (faktor-faktor) subjek, aktivitas, and kepemilikan penis; keperempuannya mengambil alih (yang terdiri dari) objek dan kepasifan" dan organ genital yang terkebiri.

Selain Kristeva, pemikir lain, Irigaray, menentang adanya sifat maskulin yang dimiliki laki-laki sebagai dominasi terhadap perempuan yang dianggap lemah. Diskriminasi secara fisik juga dialami oleh perempuan-perempuan di abad ke-20. Feminis Multikultur dan Global diawal abad ke-20 memperjuangkan kesetaraan perempuan kulit berwarna dengan perempuan kulit putih. Selain itu, perhatian mereka ditujukan untuk memberikan perhatian kepada semua orang. Perbedaan yang didasari oleh tampilan fisik ini semakin menjustifikasi fungsi perempuan sebagai other yang berbeda.

Beauvoir menyampaikan bahwa other dikenakan kepada perempuan karena rahim yang dimilikinya. Adanya rahim tersebut menjadi justifikasi laki-laki untuk menempatkan perempuan di posisi yang lebih rendah dan hanya berfungsi sebagai pelengkap reproduksi dan kegiatan seksual laki-laki. Para Feminis Posmodern kemudian muncul sebagai peredam keinginan perempuan untuk menjadi feminis yang terbaik dan mengekspresikan pikiran dan tubuh mereka dengan menulis. Tulisan, menurut Cixous, dapat menjadi media yang merepresentasikan tubuh perempuan secara simbolik atau sosial untuk mengutarakan pemikiran dengan bebas. Kedua pemikir ini melengkapi pemikiran Beauvoir dengan menghadirkan konsep baru yaitu menulis sebagai sarana mengekspresikan tubuh dan pemikiran perempuan.

Konsep-konsep yang disampaikan oleh para filsuf feminis tersebut di atas menunjukkan perjuangan yang telah dilakukan pada 
berbagai aspek kehidupan. Perjuangan ini memiliki tujuan untuk menyetarakan posisi perempuan dan laki-laki yang akan mendukung konsep ketubuhan perempuan yang lepas dari dominasi kaum patriarki. Pemikiran para filsuf feminis dapat diterapkan di dalam perkembangan filsafat dan ilmu pengetahuan. Akan tetapi dengan masalah sosial yang mengkonstruksikan perempuan, hambatan perempuan untuk mengembangkan dan membebaskan konsep ketubuhannya sendiri tetap akan dialami. Apabila hal ini masih terjadi, maka pemikiran yang disampaikan oleh Descartes bahwa filsafat dapat menjadi solusi dari permasalahan universal manusia tidak dapat disepakati (Descartes, 1984: 26).

Perempuan dapat menolak kekangan yang selama ini terjadi apabila mereka mampu memahami konsep ketubuhan patriarkis yang bersifat diskriminatif. Untuk memahami kondisi tersebut, tubuh perempuan harus dibebaskan agar dapat mempersepsi fenomena yang terjadi di dunia. Hal ini dapat diterapkan dengan memahami persepsi yang menubuh milik Merleau-Ponty untuk menyadari adanya diskriminasi yang terjadi. Dengan persepsi yang menubuh, perempuan juga dapat melihat adanya pilihan-pilihan yang dipaparkan Beauvoir sebagai ambiguitas. Persepsi yang menubuh dan kesadaran akan ambiguitas yang dipaparkan dalam tulisan inilah yang dapat membantu proses menjadi perempuan atau becoming a woman menjadi lebih mandiri tanpa adanya dominasi dari laki-laki. Selain itu, apabila kedua pemikiran tersebut diterapkan, maka filsafat dapat memberikan solusi bagi permasalahan feminisme yang terjadi.

\section{Persepsi yang Menubuh Sebagai Penolakan Konsep Ketubuhan Patriarkis}

Pemikiran Merleau-Ponty hadir sebagai tanggapan fenomenologi akan konsep dualisme mind and body yang disampaikan oleh Descartes. Pada karyanya Phenomenology of Perception, MerleauPonty hadir dengan persepsi yang menubuh yang terbagi ke dalam tiga bagian; tubuh, dunia, dan tubuh yang mendunia. Berbeda dengan pemikir fenomenologi lainnya seperti Husserl, Heidegger, maupun Sartre, Merleau-Ponty memaparkan adanya hubungan 
timbal balik di antara subjek dan objek. Hubungan tersebut terjadi karena adanya persepsi melalui tubuh sebagai media untuk mengekspresikan pemikiran manusia.

Tubuh menjadi aspek utama di dalam pemikiran MerleauPonty karena di situlah panca indera manusia dapat ditemukan. Manusia dapat memahami fenomena yang terjadi di dunia melalui panca inderanya. Konsep yang disampaikan oleh Merleau-Ponty tidak memandang manusia berdasarkan jenis kelamin atau gender yang berbeda. Oleh karena itu, seharusnya semua orang dapat menggunakan tubuhnya secara bebas untuk memahami dunia. Akan tetapi, dengan batasan yang diberikan secara sosial kepada perempuan, tubuh perempuan tidak dapat digunakan secara utuh untuk memahami kondisi di sekelilingnya. Apa yang dipahami oleh perempuan adalah konsep-konsep yang diberikan oleh laki-laki. Tubuh yang tidak bebas membuat perempuan tidak dapat mempersepsi sendiri fenomena-fenomena yang terjadi di sekelilingnya. Apabila pemikiran Merleau-Ponty dipahami dengan baik, maka seharusnya perempuan juga mendapatkan kebebasan untuk menggunakan tubuhnya dan mendapatkan wawasan baru secara mandiri.

Tubuh yang digunakan di dalam mempersepsi fenomena berhubungan dengan aspek yang kedua yaitu Dunia. Dunia yang terdiri dari Ruang, Seksualitas, Bahasa, dan Pribadi lain menjadi objek yang berada di sekeliling subjek namun dapat menjadi subjek yang timbal balik memberikan persepsi baru bagi seorang individu. Perempuan yang ditempatkan sebagai subjek berada di dalam ruang yang direpresentasikan oleh masyarakat sosial. Dengan tubuh, perempuan mampu memahami adanya konstruksi-konstruksi sosial yang dibangun di sekeliling mereka. Pemahaman tersebut juga dapat membantu perempuan membedakan diskriminasi yang diterapkan oleh laki-laki karena tubuh perempuan yang berbeda. Hal ini akan sulit dipahami apabila perempuan tidak diberikan kesempatan untuk menggunakan tubuhnya secara mandiri di dalam mempersepsi ruang tempat dia berada. Batasan yang mempersulit perempuan memahami ruang juga dialami pada aspek seksualitas. Pada aspek ini, batasan- 
batasan yang diberikan oleh masyarakat kepada perempuan didasari oleh pantas atau tidaknya hal yang berhubungan dengan seksualitas dialami oleh perempuan (Wolf, 2002: 9). Kepantasan yang dikonstruksi oleh masyarakat sosial mengekang tubuh perempuan secara langsung. Hal ini disebabkan karena perempuan menginginkan dirinya diterima oleh masyarakat sehingga perempuan berusaha menyesuaikan penampilan mereka agar menarik dan memiliki daya tarik seksual. Kondisi ini sekaligus menunjukkan bahwa perempuan masih sulit memahami aspek seksualitasnya akibat kekangan kaum patriarkis yang ada.

Setelah seksualitas, bahasa menjadi aspek berikutnya. Di dalam menyampaikan persepsi yang dihasilkan melalui pemahaman subjek dan objek, bahasa memiliki peran untuk membentuk konsep yang baru dipahami tersebut. Dengan panca indera yang dimiliki oleh tubuh, perempuan dapat memahami bahasa yang digunakan di dalam konstruksi masyarakat sosial. Batasan yang diberikan kepada perempuan juga disampaikan lewat bahasa yang dipahami bersama. Apabila perempuan dapat secara mandiri menggunakan tubuhnya untuk mempersepsi bahasa yang menyampaikan konsep pada masyarakat sosial, maka mereka dapat menghindar dari konsep ketubuhan perempuan yang dikekang oleh laki-laki dan melawan dengan menggunakan bahasa dari hasil persepsi mereka sendiri. Di dalam mempersepsi dunia, pribadi lainnya menjadi aspek yang terakhir. Subjek yang dapat menjadi objek dan sebaliknya tidak hanya melibatkan materi berupa benda. Individu lain yang sedang dihadapi juga dapat menjadi objek dan beralih menjadi subjek pada proses interpretasi. Oleh karena itu, perempuan apabila memahami persepsi yang menubuh seharusnya paham bahwa ia tidak selalu menjadi objek layaknya konsep yang disampaikan oleh pemikir-pemikir patriarkis sebelumnya. Dari pemaparan tersebut, dapat disimpulkan bahwa pada proses mempersepsi dunia, tubuh manusia membutuhkan kebebasan di dalam memahami fenomena sekelilingnya. Oleh karena itu, perempuan sudah selayaknya terlepas dari kekangan dominasi laki-laki yang ada selama ini terjadi. 
Aspek tubuh dan dunia memiliki peran bagi manusia untuk mendukung proses mengada di dunia miliknya. Pada Phenomenology of Perception, Merleau-Ponty menyatakan;

As I have two eyes, I ought to see the object double, and if I see only one of it, that is because I construct by means of two images the idea of one object a distance away. Perception becomes an 'interpretation' of the signs that our senses provide in accordance with the bodily stimuli, a 'hypothesis' that the mind evolves to 'explain its impressions to itself.' (Ponty, 1962: 38).

Ketika aku memiliki dua mata, aku mampu melihat satu objek secara ganda, dan apabila aku hanya melihat salah satu, hal tersebut dikarenakan aku membangun gagasan objek tunggal pada jarak yang jauh menggunakan dua gambar. Persepsi menjadi sebuah interpretasi dari tanda-tanda yang dihasilkan panca indera kita dalam jalinannya dengan rangsangan fisik, sebuah 'hipotesis' yang menunjukkan pikiran berkembang dan berevolusi untuk 'menjelaskan impresi (pikiran) kepada dirinya (pikiran) sendiri'.

Proses ini hadir sebagai pembentukan dari Cogito, temporalitas dan kebebasan. Cogito dapat membantu perempuan sebagai subjek melalui kesadaran akan ke-aku-an yang dimilikinya untuk memahami bahwa persepsi akan fenomena yang ada di sekitar kita merupakan kuasa diri kita sendiri sebagai subjek. Perempuan sebagai subjek juga dapat memahami bahwa temporalitas atau waktu bersifat sementara. Hal ini bertujuan agar tidak selalu berpegang pada persepsi yang lama dan dapat mengolah pengalaman-pengalaman sebelumnya ke dalam persepsi menubuh yang baru. Konsep ini mengarah pada kebebasan yang dimiliki oleh perempuan di dalam membentuk persepsi yang menubuh.

Dari paparan di atas, dapat disimpulkan bahwa apabila perempuan memahami proses persepsi yang menubuh dan aspekaspek pendukungnya, mereka dapat memahami perannya sebagai subjek dan adanya objek di sekeliling mereka dengan lebih baik. Maka persepsi yang menubuh dapat dilalui dengan baik serta 
membantu perempuan di dalam menolak ketubuhan patriarkis yang menghambat perkembangan mereka di dalam kehidupannya. Kesadaran yang menubuh tersebut akan dilengkapi dengan kesadaran akan ambiguitas milik Beauvoir agar proses menjadi perempuan atau becoming a woman dapat dialami secara mandiri tanpa dominasi dari kaum patriarki.

\section{Kesadaran akan Ambiguitas Sebagai Penolakan Konsep Ketubuhan Patriarkis}

One is not born, but rather becomes, a woman adalah kalimat yang disampaikan oleh Beauvoir pada karyanya The Second Sex. Karya yang memiliki judul asli Le Deuxième Sexe ini memaparkan bagaimana perempuan mengalami diskriminasi akibat konsep other yang selalu dilekatkan pada dirinya. Hal ini disebabkan oleh adanya rahim yang membuat laki-laki menjustifikasi rendahnya posisi perempuan di dalam kehidupan sosial.

Dari bagian pertama buku Beauvoir, pemaparan perbedaan perempuan diawali dari konsep ketubuhan yang berbeda sejak perempuan dilahirkan. Fenomena tersebut disampaikan oleh Beauvoir pada bagian Destiny. Beauvoir menelaah perilaku makhluk betina dari spesies lainnya yang juga memiliki rahim. Dari pengamatan tersebut, Beauvoir berpikir apabila makhluk betina tidak seluruhnya didominasi oleh jantan, maka perempuan tidak seharusnya ditempatkan di posisi yang lebih rendah daripada lakilaki. Pemikiran ini kemudian menunjukkan adanya peran sosial di dalam mengkonstruksi peran perempuan di lingkungannya. Hal ini menjadi justifikasi bahwa adanya rahim membuat perempuan menjadi objek atau the other dan layak ditempatkan di posisi yang lebih rendah oleh laki-laki.

Diskriminasi akibat perbedaan fisik yang dialami oleh perempuan tidak berhenti sampai konsep ketubuhannya saja. Pada bagian History di dalam The Second Sex, Beauvoir menjelaskan adanya kekangan tubuh perempuan di dalam masyarakat sosial sehingga mereka tidak dapat meraih kebebasan akan pengalaman yang setara 
dengan laki-laki. Perempuan diberikan peran yang domestik dan tidak jauh dari kehidupan berumah tangga. Batasan bagi perempuan diperburuk dengan justifikasi gereja yang memperbolehkan perempuan dihukum secara fisik apabila tidak mematuhi laki-laki yang diwakili oleh ayah, saudara laki-laki, maupun suami mereka.

Konstruksi sosial lainnya yang mengekang pergerakan tubuh perempuan dipaparkan oleh Beauvoir sebagai Myths. Mitos dibangun oleh kaum patriarki untuk menundukan perempuan. Salah satu contoh mitos adalah masalah keperawanan. Suatu kelompok masyarakat memiliki konsep bahwa istri yang baik dan cantik adalah mereka yang sudah tidak perawan. Hal ini disebabkan masyarakat tersebut percaya bahwa mereka yang masih perawan menyimpan energi negatif di dalam alat kelamin dan rahim mereka. Energi buruk tersebut dapat merugikan laki-laki pertama yang berhubungan seksual dengan perempuan tersebut. Untuk membuat perempuan patuh, maka para laki-laki menganggap istri mereka cantik dan menarik apabila sudah pernah berhubungan seksual sebelumnya. Akan tetapi, sekelompok masyarakat lainnya menyatakan bahwa perempuan yang masih perawanlah yang layak menjadi istri yang baik. Oleh karena itu perempuan juga tidak bebas mengalami pengalaman seksualnya sendiri karena harus patuh akan konstruksi sosial yang ada.

Diskriminasi akibat konstruksi sosial yang dipaparkan oleh Beauvoir di buku yang pertama tidak berhenti begitu saja. Feminis tersebut melanjutkan paparannya akan kekangan yang dialami oleh perempuan di kemudian hari yang masih terjadi. Pada buku keduanya, dijelaskan bahwa perempuan sudah mampu berkembang dan keluar dari kekangan peran domestik yang selama ini dialaminya. Akan tetapi, perbedaan yang didasari oleh kondisi fisik perempuan menyebabkan perkembangan mereka tidak sama dengan apa yang dialami oleh laki-laki. Beauvoir menyatakan

...even today woman is heavily handicapped, though her situation is beginning to change. Almost nowhere is her legal status the same as man's and frequently it is much to her disadvantage (Beauvoir, 1953: 19). 
...bahkan kini perempuan masih dianggap cacat walaupun situasinya sudah berubah. Hampir tidak ada tempat di mana status hukum perempuan tersebut sama seperti laki-laki dan seringkali hal ini merugikan mereka.

Fenomena ini menjadi titik tolak kritik yang dipaparkan di kedua bagian buku The Second Sex milik Beauvoir.

Pada fase pembentukan pengertian perempuan yang berikutnya, Beauvoir memaparkan perilaku berbeda yang diterapkan kepada anak perempuan dan laki-laki. Sejak kecil, perempuan diharapkan tidak bergerak sebebas laki-laki. Kegiatan di luar rumah yang dilakukan oleh perempuan tidak seekspresif anak laki-laki. Perempuan yang diharapkan untuk bersikap pasif juga terjadi pada tahapan berikutnya. Tahap yang dipaparkan pada The Second Sex berikutnya adalah bagaimana perempuan memiliki fungsi untuk melengkapi laki-laki pada kehidupan berumah tangga. Selain itu, kepasifan perempuan diharapkan pada pengambilan keputusan. Di dalam kehidupan berumah tangga, laki-laki atau suamilah yang dianggap layak mengambil keputusan apapun. Perempuan atau istri tidak diharapkan untuk secara aktif mengekspresikan ide-ide yang mereka miliki. Hal ini menunjukkan adanya kekangan bagi tubuh perempuan sebagai media penyaluran pemikiran yang mereka miliki. Selain itu, perempuan juga memiliki hambatan di dalam mengembangkan diri akibat konstruksi sosial yang ada.

The Second Sex menunjukkan bahwa seiring berjalannya waktu, kondisi fisik perempuan yang berbeda dengan adanya rahim akan selalu menjadi hambatan mereka untuk menjadi setara dengan lakilaki. Maka dibutuhkan perlawanan dari perempuan untuk menghilangkan konsep ketubuhan patriarkis. Hal ini dapat dilakukan apabila perempuan sadar akan diskriminasi yang terjadi sehingga ketika mereka dibebaskan maka peremuan dapat mempersepsi fenomena di sekelilingnya sendiri. Konsep persepsi yang menubuh Merleau-Ponty dapat membantu perempuan memahami dunianya secara mandiri. Selain persepsi yang menubuh, perempuan dapat menyadari ambiguitas yang dimilikinya. Perempuan memiliki pilihan 
yang dapat ditentukan olehnya sendiri. Kesadaran akan ambiguitas dijelaskan oleh Beauvoir pada bukunya yang lain The Ethics of Ambiguity.

Pada The Ethics of Ambiguity, hal yang ditekankan adalah kondisi di mana setiap orang memiliki kebebasan di dalam memilih tujuan hidup untuk menunjukan eksistensi dirinya. Beauvoir memaparkan adanya enam tahap kebebasan manusia. Keenam tahapan tersebut adalah sub-man, serious man, nihilist, adventurer, passionate man cares, dan genuine freedom. Kebebasan di dalam kategori tersebut dipaparkan secara bertahap dari masa anak-anak hingga dewasa. Hal tersebut menunjukkan adanya proses di dalam menyadari tujuan serta pilihan hidup setiap orang. Selain itu, di dalam memilih tujuan hidupnya, seseorang digambarkan oleh Beuvoir mengambil lima tindakan yang berbeda. Kelimanya adalah The Aesthetic Attitude, Freedom and Liberation, The Antinomies of Action, The Present and The Future, dan Ambiguity. Keputusan dan tindakan yang diambil oleh seseorang tentunya dapat didukung dengan persepsi yang menubuh. Dengan kemampuan untuk mempersepsi secara menubuh, maka ia mampu memahami sendiri bahwa ia memiliki pilihan untuk mendukung perjalanan hidupnya.

Persepsi yang menubuh dan kesadaran akan ambiguitas sebagai jawaban filsafat membutuhkan fungsi praksis agar mampu menjadi solusi bagi permasalahan feminisme di dalam menolak konsep ketubuhan patriarkis. Sebagai contoh, salah satu perempuan yang menolak konsep ketubuhan patriarki adalah model bernama Ashley Graham. Graham tidak memiliki tubuh yang serupa dengan model-model lainnya. Tubuhnya yang relative besar membuatnya menjadi model plus-sized. Pada wawancaranya dengan majalah Vogue, ia menyatakan :

"Do I sometimes wish I were thinner? God, in the old days, absolutely I did, but now I feel that to lose weight would be disloyal to myself," she explained. "A lot of who I am is connected to my size, and I am so happy with who I am." (Graham, 2016: 1) 
"Apakah saya terkadang berharap kurus?" demi Tuhan, di masa lalu, sudah pasti saya menginginkan itu, tetapi sekarang saya merasa bahwa mengurangi berat badan adalah pengkhianatan terhadap diri saya sendiri," tuturnya. "Seringkali identitas saya dihubungkan dengan ukuran tubuh saya, dan saya bahagia dengan diri saya sendiri."

Wawancara tersebut menunjukkan adanya penolakan dari Graham terhadap konstruksi sosial yang selama ini ada dan mengekang tubuh perempuan. Graham menunjukkan adanya persepsi yang menubuh yang membuatnya paham bahwa konsep model yang selama ini diminati adalah konstruksi dari kaum patriarki. Ia juga paham bahwa ia memiliki pilihan untuk keluar dari kekangan yang ada dan mewujudkan cita-citanya sendiri. Hal ini menunjukkan bahwa Graham sadar akan ambiguitasnya. Perlawanan Graham sesuai dengan violence yang dipaparkan oleh Beauvoir sebagai gebrakan bagi kekangan konsep ketubuhan patriarkis. Hal ini menunjukkan adanya antinomies of action, seperti apa yang disampaikan oleh Merleauponty, yang menjadi kesadaran Graham akan ambiguitasnya untuk menentukan pilihan secara bebas.

Selain contoh dobrakan perempuan terhadap konsep ketubuhan patriarkis secara fisik, contoh berikutnya adalah ilmuwan bernama Elizabeth Blackburn yang keluar dari kekangan konsep ketubuhan patriarkis secara sosial. Di masa kecilnya Blackburn mengalami perbincangan dengan saudara laki-lakinya sebagai berikut:

"I said, 'I'm going to be a scientist.' And he said, 'What a nice girl like you doing going into science?' I was shocked and so mad that I didn't know what to say in response. So I kept my mouth shut, but I was all the more determined. In a way, I'm quite grateful to that man." (Blackburn, 2017, hal. 49)

“Saya berkata, 'Saya akan menjadi seorang ilmuwan.' Dan ia membalas, 'Apa yang akan dilakukan perempuan baik sepertimu di bidang ilmiah?' Saya terkejut dan sangat marah 
hingga tidak tahu harus menjawab apa. Jadi saya diam tetapi menjadi sangat termotivasi. Di sisi lain, saya cukup bersyukur dengan respons laki-laki tersebut."

Blackburn merespon pembicaraan tersebut dengan membuktikan bahwa ia mampu menjadi ilmuwan perempuan seperti yang sudah diimpikan. Serupa dengan Graham, Blackburn melakukan penolakan terhadap objek yang berupa konsep peranan perempuan di dalam kehidupan sosial. Ilmuwan ini menguasai tubuhnya secara menyeluruh sehingga mampu melakukan persepsi yang menubuh terhadap dunianya. Hal ini membuat Blackburn mampu memilih jalan hidupnya sendiri. Violence yang ia lakukan terbukti mampu melawan konsep ketubuhan patriarkis secara sosial yang selama ini mengekang perempuan dari prestasi-prestasi yang setara dengan lakilaki.

Berdasarkan pemaparan dan beberapa contoh yang telah dipaparkan atas dapat disimpulkan bahwa pemikiran Merleau-Ponty dan Beauvoir dapat menyumbangkan dukungan di dalam permasalahan feminisme. Dukungan tersebut berupa basis-basis argumentasi filosofis untuk mengesampingkan konsep ketubuhan patriarkis di dalam berbagai pemikiran dan kehidupan serta tidak mendiskriminasi peranan perempuan di dalam perkembangan pemikiran filsafat itu sendiri. Dengan demikian maka klaim bahwa filsafat merupakan solusi bagi masalah manusia dapat diterima.

\section{SIMPULAN}

Sebagai sebuah kesatuan, mind dan body tidak dapat dipisahkan. Akan tetapi, pemikiran-pemikiran yang muncul dari para filsuf ternyata memberikan konsep ketubuhan yang berbeda di antara perempuan dan laki-laki. Hal inilah yang kemudian menjadi pemicu adanya diskriminasi perlakuan yang diberikan kepada perempuan dan laki-laki.

Diskriminasi tersebut memiliki kecenderungan yang mengekang tubuh perempuan di dalam mengekspresikan pemikiranpemikiran mereka. Keterbatasan yang diberikan membuat 
perempuan mengalami hambatan di dalam proses menjadi perempuan atau becoming a woman seperti yang dikemukakan oleh Beauvoir. Di dalam proses yang terjadi pada seluruh proses kehidupan yang dijalani perempuan, penolakan ketubuhan patriarki dapat dilakukan dengan menggunakan konsep persepsi yang menubuh milik Merleau-Ponty dan kesadaran akan ambiguitas milik Beauvoir. Melalui dua mekanisme tersebut diharapkan perempuan mampu menjalani proses menjadi perempuan atau becoming a woman dengan baik. Pada akhirnya, penerapan hasil pemikiran dari kedua filsuf asal Prancis tersebut di atas akan dapat menentukan mampu atau tidaknya filsafat menjadi jawaban bagi masalah universal manusia seperti yang sudah disampaikan oleh Descartes.

\section{DAFTAR PUSTAKA}

Agonito, R., 1977, History of Ideas on Woman, The Berkley Publishing Group, New York.

Arivia, G., 2003, Filsafat Berperspektif Feminis, Yayasan Jurnal Perempuan, Jakarta.

Asante, M. K., \& Mazama, A., 2005, Encyclopedia of Black Studies, SAGE Publications, California.

Beauvoir, S. d., 1953, The Second Sex, Lowe and Brydone, London.

Bennett, J., 2017, Some Text From Early Modern Philosophy, http://www.earlymoderntexts.com/. (Diakses pada 3 April 2017)

Blackburn, E., 2017, "Firsts Women Who Are Changing The World", dalam TIME , San Fransisco.

Descartes, R., 1984, "Meditation on First Philosophy", dalam J. Cottingham, R. Stoothoff, \& D. Murdoch, The Philosophical Writings of Decartes Volume II, Cambridge University Press, Cambridge. 
Freud, S., 1920, A General Introduction to Psychoanalysis, Boni and Liveright, New York.

Friedan, B, 2013, "The Problem That Has No Name", dalam W. K. Kolmar, \& F. Bartkowski, Feminist Theory A Reader, McGrawHill, New York.

Graham, A., 2016, "Why Ashley's Our Girl", British Vogue, http://www.vogue.co.uk/article/ashley-graham-january-voguecover-star-interview-preview. (Diakses pada 4 Desember 2017)

Irigaray, L., 1985, This Sex Which is Not One, Cornell University Press, New York.

Kant, I., 1977, "The Interrelations of The Two Sexes", dalam R. Agonito, History of Ideas on Woman, The Berkeley Publishing Group, New York.

Leahy, L., 2001, Siapakah Manusia?, Kanisius, Yogyakarta.

Merleau-Ponty, M., 1962, Phenomenology of Perception, diterjemahkan C. Smith, Routledge, Routledge.

Wolf, N., 2002, The Beauty Myth, Harper Collins, New York.

Woolhouse, R., 1993, The Concept of Substance in Seventeenth Century Metaphysics, Routledge, London.

Wollstonecraft, M., 2013, "A Vindication of the Rights of Woman" dalam W. K. Kolmar, \& F. Bartkowski, Feminist Theory A Reader, McGraw-Hill, New York. 